\begin{tabular}{l}
$\begin{array}{l}\text { Journal of Economics and Behavioral Studies (ISSN: 2220-6140) } \\
\text { Vol. 9, No. 5, pp. 106-121, October } 2017\end{array}$ \\
\hline \hline
\end{tabular}

\title{
South African Sucrose Quality in Sugar: Determinants and its Empirical Implications
}

\author{
Mishelle Doorasamy, Bruce Rhodes \\ University of KwaZulu-Natal, Westville Campus, Durban, South Africa \\ doorasamym@ukzn.ac.za, Rhodesb@ukzn.ac.za
}

\begin{abstract}
The study investigates which factors determine sucrose quality in the South African sugar cane production process. Though South Africa is the $8^{\text {th }}$ largest producer of sugar cane in the world and the highest in Africa, a decline has been observed in the production of high quality sugar in the country. The study adopts the Auto Regressive Distributive Lags (ARDL) technique to analyze sugar cane production time series data from 1980 to 2016 in South Africa. Ten variables were tested, including Average Temperature, Stalk growth, Evaporation, and Soil Water Content $(100 \mathrm{~mm})$. Our findings revealed that on both the short and long run, some of the variables investigated have the tendency of increasing sucrose level in sugar cane while an increase in other variables would decrease sucrose level altogether. However, the impact of Soil Water Content $(100 \mathrm{~mm})$ appears not to be statistically significant on sucrose production in our regression model in the short and long run. Of special interest are Stalk growth (Reference sugar cane) and average temperature, as their values are more significantly germane as regards the quantity of sucrose obtained during sugar cane processing in South Africa.
\end{abstract}

Keywords: Sugar, Can Production, South Africa, Auto Regressive Distributive Lags

\section{Introduction}

The South African sugarcane industry is a diverse one involving both the agricultural cultivation processes, as well as the industrial production of sugars, syrups, and a range of by-products. It is a significant part of the country's agricultural economy with an average sugar output of 2.2 million tons per season (second only to maize), and is mostly centred in KwaZulu-Natal. Southern African Customs Union (SACU) is a market to about $60 \%$ of this sugar produced in South Africa and in combination with the world export market, contributes around R8 billion per annum to the South African economy and about R2.5 billion per annum to export earnings for the country. The average value of sugar cane production is R5.1 billion per annum, which is $17.4 \%$ of the total gross value of annual field crop production in South Africa. The industry supports 79,000 direct job and another 270,000 indirect job opportunities. It is estimated to provide sustainable livelihoods to about 1 million people (Tongaat, 2012). A total land mass of 430000 hectares is engaged for the cultivation of Sugar cane in South Africa, covering about fourteen major provinces bordered by the Northern Pongola in the North and the Mpumalanga Low veld in the South. Mostly, a major proportion of about $68 \%$ of this land mass area is the approximate distance of $30 \mathrm{~km}$ away from the coastal region, while about $17 \%$ known for its high rainfall is located within the province of KwaZulu-Natal. The largely irrigated Northern Pongola and Mpumalanga Low veld areas makes up the remaining part of the total land area utilised for the growing of sugar cane in South Africa (Anon, 2016).

A highly complex system of molecular colloidal and suspended non-sugars and real sugars is the component extracted from the raw sugar cane juice, and the quality of extracted sugar largely depends on the percentage between the two categories of components. The quantity of sugar that could be extracted per ton of cane crushed is of great interest to a sugar cane miller in any given industry. All other things are a liability to the miller as this sucrose quality is the part which remains as an asset to him. Hence, the smaller the quantity amount of sugar cane per ton of sugar produced from the crushed cane, the lower the impurities level, the much easier it become for him to extract juice from the crystallize sugar. High level of sucrose and purity constitute the major factors that impact on a high rate of sugar recovery, level of non-sugars and low fibre. The nature and quantity of non-sugars found in the sugar cane is particularly important, as they have an impact on processing and refining costs. Sucrose content is therefore an all-important economic factor (Meyer and Wood, 2001). In fact, the days when sugar cane was paid for on a cane tonnage basis are long past. At present, one often hears that experimental results and even field yields should be given in tons sucrose per acre or tons sucrose per acre per unit time. 
Sugar cane processing has made a wide range of contributions to the South African economy. Foremost, as has been earlier stated, is the high revenue the sugar cane industry generates. Secondly, approximately 77 000 jobs are provided to the South African populace through direct employment in the production and processing of sugar cane, and another 350000 in other related support industries. Furthermore, South Africa has an approximate Figure of registered 35300 cane growers. Relatively, an average of about one million individuals, this Figure is more than about $\%$ population of South Africans who solely rely on the cane sugar industry for their daily sustenance. In addition, the sugar industry has immensely offered support in education to the economy. The launched 1965 project of Sugar Industry Trust Fund for Education (SITFE) which began as an initiative from the private sector has been able to provide bursaries date to more than 10 000 higher education learners, through her supported school building projects and tertiary institutions worked towards the improvement of overall education standards in conjunction with community-based educational authorities.

Given the highlighted contributions of sugar cane to the South African economy, factors contributing to the quality of sugar cane content in the industry have a possible influence on its contribution to the total GDP of the agricultural sector, and hence, to the overall economy (Deressa, Hassan, \& Poonyth, 2005). However, from a recent report on the South African sugar cane production industry which has been ranked fifteenth in the world with a production rate of 2.3 million tons per year of sugar, there has been a decline in both quality and quantity of the sugar produced (Anon, 2014).The rapid rate at which lifestyle diseases such as obesity, cardiovascular disease and obesity are growing, especially among children, and the popular belief that fat and sugar consumption is responsible, has led the media and policy makers to have a negative attitude towards sugar production and consumption. However, such speculations are a result of unbalanced and scientifically flawed reporting about the role of sugar in the make-up of a balanced diet. Sugar is extracted from sugar cane, which is a natural plant. It is therefore completely natural, and a pure source of carbohydrate. Sugars contained in plants naturally occur in three forms - sucrose, glucose, and fructose. The sucrose obtained from sugar cane is no different from that obtained from other fruits and vegetables. In fact, all carbohydrate-rich foods, once digested, are converted into glucose, the body's primary source of energy. Prominent health bodies such as the World Health Organization and the Food and Agricultural Organization have confirmed that there is no clear-cut evidence of sugar being the direct cause of lifestyle diseases. Rather, they have shown that it is an indispensable part of any balanced diet.

South African sugar mills' main focus is to optimally extract sugar from sugar cane (Eggleston, 2010). The introduction of diffusion over the years as a preferred method of sugar cane extraction has to an extent improved the rate of sucrose extraction (Rein, 2007). The length of the South African milling session is usually 9 months, starting in April and ending in December (Moor and Wynne, 2001). Rein (2007) and Eggleston (2010) posited that about $98 \%$ of extractions from sucrose is obtained in South African sugar mills. However, Wynne and Groom (2003) objected, arguing that the 98\% extraction rate cannot always the case. Rather, it is the length of the milling session in South Africa that determines sucrose content recorded for a particular season at a mill. Findings indicate that there is a bell-shaped path that appears typical in the South Africa season to sugar cane sucrose content curve, the month of July being the usual peak. Throughout the season, sugar cane quality differs influenced by factors such as the sugar cane cultivar grown, weather, preor post- harvest delay, and the age of the crop. At the starting and ending periods of the milling season, the recovery rate of sucrose is always lower, majorly as a result of cane quality fluctuations throughout the season and wet weather during harvesting (Kwenda, 2015). The duration of the season is determined by the amount of recoverable sucrose in the sugar cane plant. In the period from about the middle of March to the middle of December, the sucrose content is sufficient to allow for commercially viable extraction. Although the sucrose content tapers off at either end of the harvesting season, the total sugar content is still sufficient to allow for profitable bio ethanol production (Tongaat, 2012). 
Figure 1: Extended sugar season

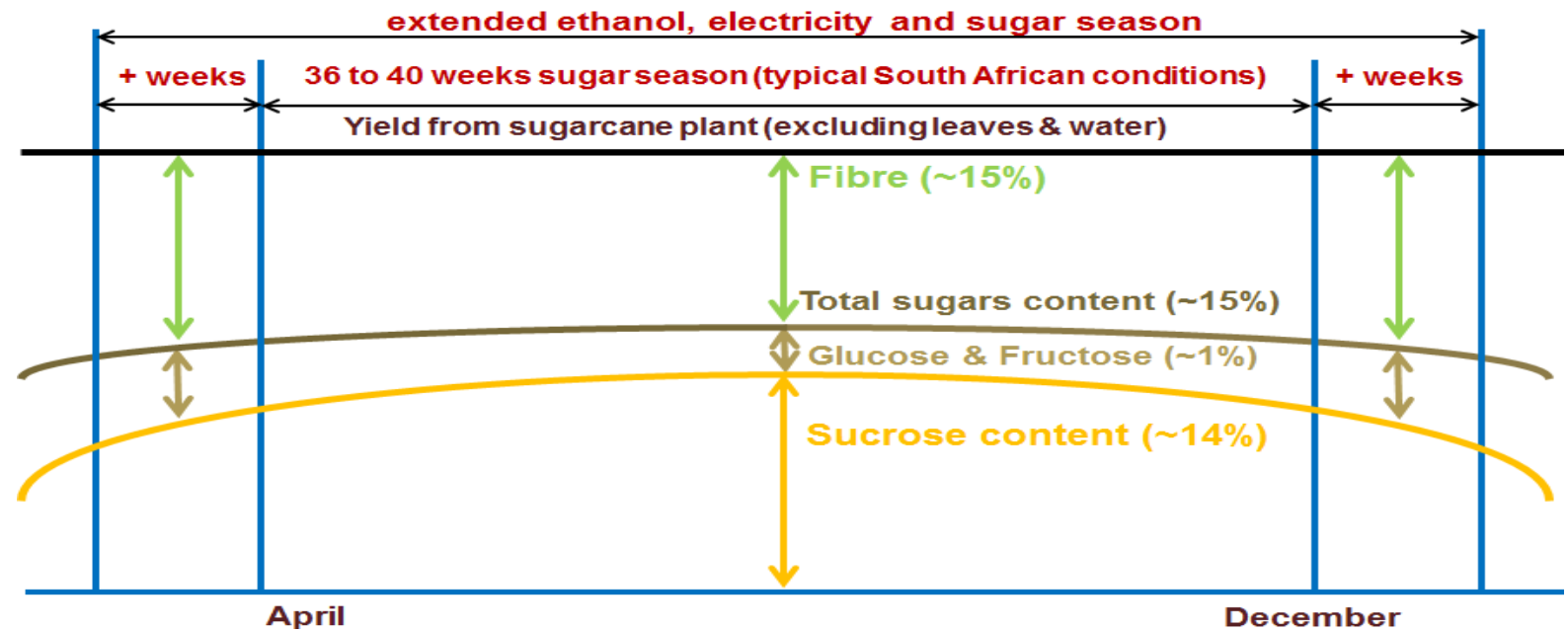

The extension of the sugar season is therefore also associated with additional sugar cane to be processed. This requires a further expansion of the area under sugar cane by about $12.5 \%$. This expansion is only feasible in combination with bio ethanol production and access to bio ethanol markets.

The Sucrose Cycle in Sugar Cane: Sucrose is produced in sugar cane leaves (the "production site") through photosynthesis and transported to the stem (the "storage site") via the phloem. It is then either stored or converted to glucose and fructose which are used to provide the energy required for new growth. Although new growth reduces the sucrose content in the stem, it is most important, since it allows the plant ("factory") to increase both its sucrose production and storage sites (Whittaker and Botha, 1997). After the new growth phase, the cane undergoes the maturation stage where all fructose, glucose, and other soluble carbons are reconverted to sucrose for storage (Whittaker and Botha, 1997). It is worthy of note that even with optimal maturation conditions, a low yield cannot be overcome if the new growth stage was not efficient and led to poor (low yield) or excessive (low sucrose, but high fiber) cane growth. Scientists have made significant efforts to discover ways in which the growth process can be understood and manipulated to lead to highsucrose cane yields, but with very little success. In addition, factors like climate and water availability which also affect the efficiency of this stage are out of the farmer's control. However, one thing that can be done to ensure high-sucrose produce is to ensure proper and adequate crop nutrition (Wang, Peng, Li, Bi, Legros, Lim, and Sokhansanj, 2013).

Figure 2: The sugar cane sucrose cycle

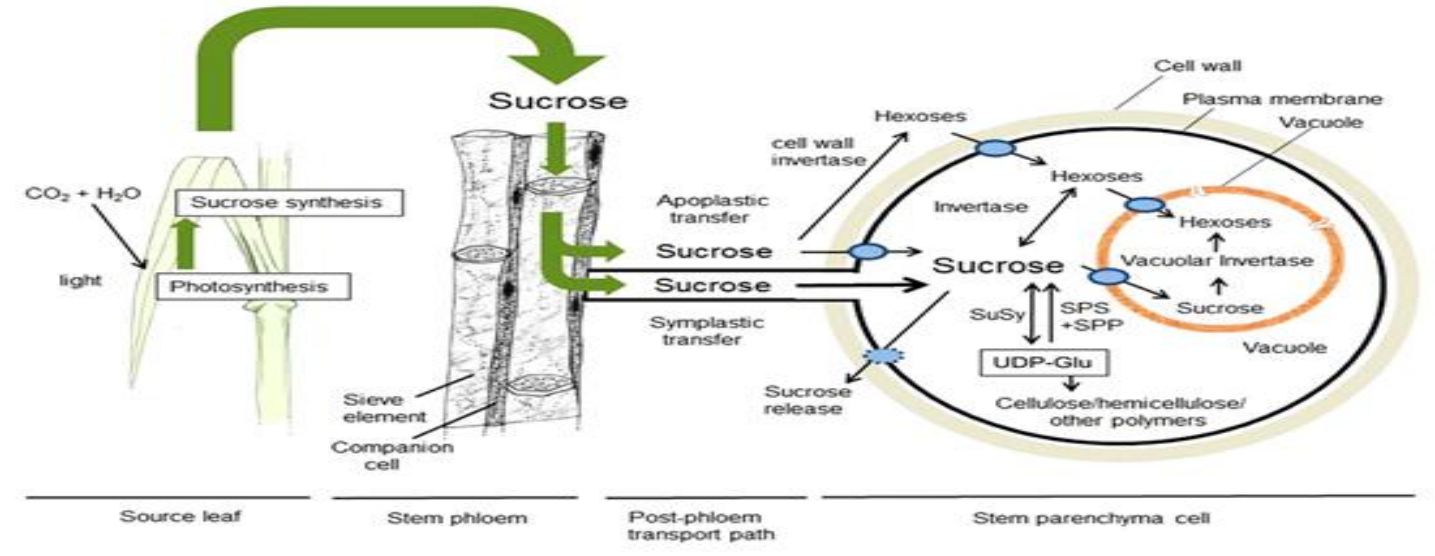

Source: Wang et al. (2013) 
There are various factors that determine the quality of sucrose and other components in sugar cane, as can be seen from the literature. These identified factors include topping height, correct selection of varieties, harvest to crush delays harvesting practices, pest infestation, occurrences of diseases, fertiliser management practices, soil type and the use of chemical ripeners. Practices in fertilizer management have the tendencies of impacting directly on the quality of chemical in the sugar cane juice produced, for non-sucrose parameters as well as sucrose content, (such as starch, gums, ash and phenols) and this can to a great extent determine the quantity amount of recovered sugar in the streaming processes (Wood, 1982). The limited research available regarding sugar loss during the processing of sugar cane highlights these factors as responsible: method of storage and harvesting, cane variety, whether the cane is cut whole stock or billeted, and the level of cane contamination during cutting and storage. These attributes differ by country (Orgeron, 2012).

Table 1: South African Sugar Cane Varieties and their Characteristics

\begin{tabular}{|c|c|c|c|c|c|c|c|c|c|}
\hline Variety & $\begin{array}{l}\text { Parenta } \\
\text { ge }\end{array}$ & Origin & $\begin{array}{l}\text { Year of } \\
\text { Release }\end{array}$ & $\begin{array}{l}\text { Cane yield } \\
\text { and RV } \\
\text { (sucrose } \\
\text { content) }\end{array}$ & $\begin{array}{l}\text { Disease } \\
\text { Susceptibil } \\
\text { ity }\end{array}$ & $\begin{array}{l}\text { Recommended } \\
\text { Harvesting } \\
\text { Practices }\end{array}$ & $\begin{array}{l}\text { Recommended } \\
\text { Planting } \\
\text { Conditions }\end{array}$ & $\begin{array}{l}\text { Ratooning, water stress } \\
\text { recovery and response to } \\
\text { ripeners }\end{array}$ & $\begin{array}{l}\text { Other } \\
\text { remarks }\end{array}$ \\
\hline N12 & $\begin{array}{l}\mathrm{NCo} 376 \\
\mathrm{x} \operatorname{Co331}\end{array}$ & & 1979 & High RV. & $\begin{array}{l}\text { Resistant to } \\
\text { eldana and } \\
\text { brown rust. } \\
\text { Susceptible } \\
\text { to mosaic. }\end{array}$ & $\begin{array}{l}\text { Must } \quad \text { be } \\
\text { harvested older } \\
\text { than } 18 \text { months }\end{array}$ & $\begin{array}{l}\text { Variety of soils in } \\
\text { rain-fed regions. } \\
\text { Relatively poor } \\
\text { performance on } \\
\text { humid soils and on } \\
\text { frost pockets. }\end{array}$ & Good ratooning ability & $\begin{array}{l}\text { Hardy } \\
\text { variety } \\
\text { which } \\
\text { performs } \\
\text { well in a } \\
\text { variety of } \\
\text { conditions. }\end{array}$ \\
\hline N14 & N7 x MP & $\begin{array}{l}\text { SASRI, } \\
\text { South Africa }\end{array}$ & 1980 & $\begin{array}{l}\text { Low RV, } \\
\text { high yield. }\end{array}$ & $\begin{array}{l}\text { Resistant to } \\
\text { lodging. } \\
\text { Susceptible } \\
\text { to eldana, } \\
\text { highly } \\
\text { susceptible } \\
\text { to RSD with } \\
\text { high spread } \\
\text { rate and } \\
\text { losses }\end{array}$ & $\begin{array}{l}\text { Annual } \\
\text { harvesting at } \\
\text { mid-late season. } \\
\text { Do not harvest } \\
\text { after mid- } \\
\text { October. Poor } \\
\text { cane yields after } \\
\text { mid-August. }\end{array}$ & $\begin{array}{l}\text { Not suitable for } \\
\text { weak, shallow, or } \\
\text { poorly-drained } \\
\text { soils. }\end{array}$ & $\begin{array}{l}\text { Poor water stress recovery, } \\
\text { poor response to ripeners } \\
\text { (Fusilade and Gallant), no } \\
\text { response to Ethephon. }\end{array}$ & $\begin{array}{l}\text { Requires } \\
\text { high } \\
\text { application } \\
\text { of } \mathrm{N} \text { and } \mathrm{K} \\
\text { fertilizers. } \\
\text { Should not } \\
\text { be planted } \\
\text { too far away } \\
\text { from the } \\
\text { mill. }\end{array}$ \\
\hline N16 & $\begin{array}{l}\mathrm{NC} 376 \\
\mathrm{x} \operatorname{Co3} 31\end{array}$ & & 1982 & $\begin{array}{l}\text { High RV, } \\
\text { high yield. }\end{array}$ & $\begin{array}{l}\text { Susceptible } \\
\text { to eldana, } \\
\text { smut, } \\
\text { tawny, and } \\
\text { brown rust. }\end{array}$ & $\begin{array}{l}\text { Long cycle } \\
\text { harvesting (more } \\
\text { than } 15 \text { months } \\
\text { old). }\end{array}$ & $\begin{array}{l}\text { Humid soils in the } \\
\text { Midlands and } \\
\text { Hinterland. Usable } \\
\text { in frost pockets. } \\
\text { Performs poorly on } \\
\text { shallow and sandy } \\
\text { soils. }\end{array}$ & Poor water stress recovery. & $\begin{array}{l}\text { Shows rapid } \\
\text { stalk } \\
\text { elongation } \\
\text { and a high } \\
\text { population } \\
\text { of erect } \\
\text { stalks, } \\
\text { leading to } \\
\text { generally } \\
\text { good } \\
\text { payloads. }\end{array}$ \\
\hline N17 & $\begin{array}{l}\mathrm{NCo} 376 \\
\mathrm{x} \\
\mathrm{CB} 38 / 22\end{array}$ & $\begin{array}{l}\text { SASRI, } \\
\text { South Africa }\end{array}$ & 1984 & $\begin{array}{l}\text { Moderate- } \\
\text { high RV, } \\
\text { low- } \\
\text { moderate } \\
\text { yield }\end{array}$ & & $\begin{array}{l}\text { Annually along } \\
\text { the coast. Must be } \\
\text { harvested in } \\
\text { summer (mid- } \\
\text { late season). }\end{array}$ & $\begin{array}{l}\text { Well-drained soils } \\
\text { (sandy to sandy clay } \\
\text { loams and heavy } \\
\text { clay). Best results } \\
\text { have been obtained } \\
\text { on the North Coast } \\
\text { and Zululand. }\end{array}$ & $\begin{array}{l}\text { Poor ratooning ability in } \\
\text { winter. }\end{array}$ & \\
\hline N19 & $\begin{array}{l}\mathrm{NCo} 376 \\
\mathrm{x} \\
\mathrm{CB} 40 / 35\end{array}$ & $\begin{array}{l}\text { SASRI, } \\
\text { South } \\
\text { Africa. }\end{array}$ & $\begin{array}{l}1986 \\
\text { (North) / } \\
1989 \\
\text { (South) }\end{array}$ & $\begin{array}{l}\text { Very high } \\
\text { RV, low }\end{array}$ & $\begin{array}{l}\text { Susceptible } \\
\text { to mosaic. }\end{array}$ & $\begin{array}{l}\text { Annual } \\
\text { harvesting. }\end{array}$ & $\begin{array}{l}\text { Performs well on a } \\
\text { range of soils (good } \\
\text { alluvium, dolerite, } \\
\text { Vryheid sediments) } \\
\text { with proper } \\
\text { irrigation. }\end{array}$ & & $\begin{array}{l}\text { Requires } \\
\text { favorable } \\
\text { rain-fed } \\
\text { conditions to } \\
\text { reach its } \\
\text { potential of } \\
\text { very high RV. }\end{array}$ \\
\hline N21 & $\begin{array}{l}\text { CB38/22 } \\
\mathrm{x} \\
\mathrm{N} 52 / 214\end{array}$ & $\begin{array}{l}\text { SASRI, } \\
\text { South } \\
\text { Africa. }\end{array}$ & 1989 & $\begin{array}{l}\text { Moderate } \\
\text { RV, high } \\
\text { yield }\end{array}$ & $\begin{array}{l}\text { Resistant to } \\
\text { eldana. } \\
\text { Susceptible } \\
\text { to lodging } \\
\text { with late } \\
(16-20) \\
\text { month } \\
\text { harvesting. }\end{array}$ & $\begin{array}{l}\text { Harvest at } 14- \\
15 \text { months if } \\
\text { planted in Spring, } \\
\text { and at } 16-20 \\
\text { months if planted } \\
\text { in Autumn. }\end{array}$ & $\begin{array}{l}\text { Performs well on a } \\
\text { range of soils (NGS } \\
\text { Ordinary, Dwyka, } \\
\text { tillite, granites), } \\
\text { preferably on soils } \\
\text { with above } 12 \% \\
\text { clay content. }\end{array}$ & $\begin{array}{l}\text { Good water } \\
\text { resistance. }\end{array}$ & $\begin{array}{l}\text { This variety } \\
\text { actually } \\
\text { performs } \\
\text { better under } \\
\text { stressed } \\
\text { conditions } \\
\text { and when } \\
\text { eldana levels }\end{array}$ \\
\hline
\end{tabular}




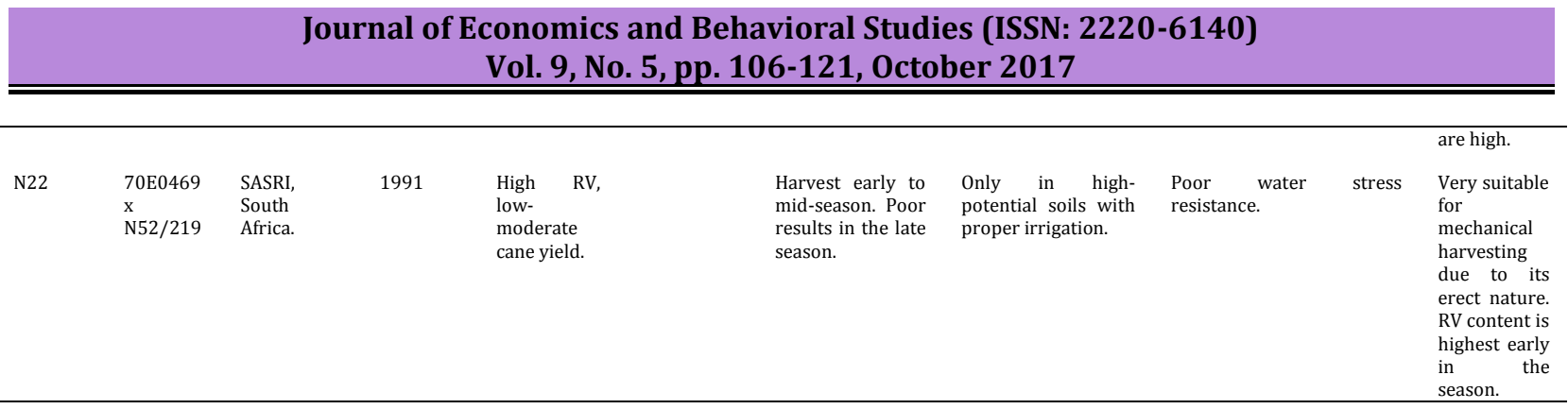

Problem Statement: Customers' demand for high-quality sugar puts pressure on harvester operators and growers to focus on delivering sugar cane with high-quality content. However, this could be detrimental to the maintenance of sucrose quality, as it can lead to them pushing machine harvesters beyond their capacity, resulting in increased losses in sugar and sucrose. The imbalance between quality maintenance and the quest to meet customers' demand is a major challenge to cane growers in South Africa. Certain harvesting methods have been argued by policy makers that factors such as lower ground speed and lower pour rate could assist to reduce the loss in cane and damages of soil during the period of harvesting. It has however been noticed that such practices apparently increase harvesting cost significantly. A cane with high-quality sucrose would certainly possess a higher amount of Commercial Cane Sugar and hence improve profitability and growers returns; however, with the present harvesting prices, it is really difficult to produce an economically highquality cane. The importance of understanding the factors that determine sucrose quality is shown by the priority of sucrose content among other components of sugar cane, as has been earlier discussed. The inability to effectively manage the economic pressure from various cane growing stages spanning plantation through harvesting results in short billets, high cleaning losses and excess stool damage. This in turn leads to a lower quality product being delivered. Addressing this major challenge is a major gap in the literature which this study is out to investigate.

Objectives of the study: The broad objective of this study is to determine the relationship between sucrose and the factors that determine its quality.

The specific objectives are to:

- To identify which factors determine sucrose quality in the South African sugar cane growing industry.

- To investigate to what extent these sucrose quality determinants impact on the profitability of sugar cane production in South Africa.

\section{Theoretical Foundation and Empirical Analysis}

The relevance of empirical analyses is hinged on the need to prove that the concepts in the study relate adequately with extant theories on sucrose formation. Not much work on theories that established the processes of sucrose formation in sugar cane can be found in literature. This could be as a result of individual interest in other fields of study at the expense of sugar production. However, some of the existing theories are reviewed herein. The theoretical background behind sucrose formation can be traced to Buchanan (1976), who found in his simple time regression analysis an inverse relationship between sucrose, harvestable components and water related contents. In addition, Rein (2007) and Meyer et al. (2013) posit that evaporation forms the heart of a sugar mill and is also the determining factor of the factory's steam economy. According to this argument, raw juice, which contains about $0.5 \%$ suspended solids, is heated up to nearboiling point and sent off to the evaporation system (Jorge et al., 2010). Evaporation involves the removal of water from sugar cane juice with the aim of attaining a solid concentration of about $60-65^{\circ}$ Brix and an invert sugar composition of about $3.5-4.5 \%$. Juice concentration then is reduced to a value just under the saturation point, after which crystallisation is initiated. This is done so as to get a cane juice concentrate with as little steam consumption, sucrose loss and colour formation as possible (Kwenda, 2015). Kwenda (2015) further postulates that a number of factors affect the efficiency of diffusers in the process of sucrose formation, such as cane preparation and residence time, imbibitions and percolation rates, the number of diffuser stages, flooding, and temperature. These factors should be taken into consideration and monitored if high sucrose extraction efficiency levels are to be maintained. 
An impact factor which needs to be considered in the overall sugar production process is the environmental effects of sugar cane production processes. The choice of technologies applied in agronomic and agroprocessing practices largely determine the environmental impact of the production process. The major environmental effects are air pollution from pre-harvest sugarcane burning (to facilitate cutting), water pollution, and soil erosion and compaction. Soil degradation through erosion and compaction happens as a result of intense mechanization (traffic of heavy machinery) and failure to implement best cultivation management practices, and has a negative impact on sugarcane yields (Martinelli and Filoso, 2008). Erosion problems become worse off by Compaction because it decreases water infiltration, reduce soil porosity, and ultimately increase runoff (Martinelli and Filoso 2008). The major source of soil degradation is during periods such as replanting of yields, land conversion, the time lag between next canopy closure and crop harvesting. During this time frame, the soil condition is left barren whereas this fallowing periods subject the soil to erosive forces of wind and rain. Even the wild vegetation, necessary conversion of natural and extensive pastoral conversion of land into cultivating fields of cane sugar exposes the soil to the risk of degradation. For instance, a research conducted in 2001at São Paulo, indicates a sharp increase in erosion rates to about $2 \mathrm{Mg} /$ hayear to $30 \mathrm{Mg}$ /hayear. This deterioration was observed take place among sugar cane fields, pastures and other natural vegetation. This high level of soil erosion allows deposition of sediment into reserved water, streams, wetlands, as well as rivers (Sparovek and Schnug, 2001).

According to Kwenda (2015), the sugar cane milling process is basically comprised of eight steps: cane preparation, sucrose extraction, raw juice clarification, filtration, evaporation, syrup clarification, crystallization, and centrifugal separation. Sucrose loss is experienced at each of these stages. It is therefore essential to review the major vulnerabilities of the product (sucrose) throughout the process, since the sugar cane industry is a complex system that requires efficient risk management capabilities. Watanabe et al. (2016) conducted a study which addressed some basic nutrients found in sugar cane juice and their main objective is to identifying the fundamental factors impacting on the quality of sugar cane. Sugar cane samples were collected between year 2013 and 2015 from all various milling stations where sugar cane is processed in Japan. This process helped to investigate the nexus between sucrose concentration and juice nutrients. Their findings based on the collected juice indicates that chloride $(\mathrm{Cl}-)$ and potassium $(\mathrm{K}+)$ are the major components present most in the juice of the cane sugar, and these two components correlate negatively with the concentration of sucrose in sugar cane. Furthermore, their result further established that the production area significantly contribute to the concentrations of chloride and potassium respectively, while those sugar cane with high content of $\mathrm{Cl}-$ and $\mathrm{K}+$ concentrations reflects low concentration of sucrose.

Again, Buchanan (1976) focussed on the analysis of the statistical trends in sugar cane yields and quality and for a period of 25 seasons. It was indicated that although there were increasing rise in the production cost and a comparable decline in the quality cane sugar caused by an improved cane yields, the greater amount of sugar recovered (particularly when factory performance is not included) and its outcome returns increase more than was compensated for it. The study further indicates that there is evidence of possible gains that could be derived from economic advantage gotten in some certain situations from the processing of tops especially when leaves are not included). In other to further examine this, time series simple regression analysis was adopted, and the findings revealed from the statistical trends in cane yield and quality that there is economic support in the decline of the quality in cane provided there is a continued yield increase. Again, the study recommended that quality from cane sugar alone must not be the only priority at the expense of other factors. The significant impacts of temperature on the production of quality of sugarcane was the concern in Deressa, Hassan \& Poonyth (2005) study. Having adopted a Ricardian model that integrated farmers' adaptation to investigate the effects of climate change on Sugarcane production in South African under dry-land and irrigation conditions. The research was built on a pooled data of 11 districts where time series data for a period 1977 to 1998 were adopted. The Result outcome indicates that changes in climate have nonlinear significant effects on South Africa net revenue per hectare of sugarcane. The result support possible future influence of increases in temperature than precipitation. Furthermore, the study also noted that irrigation cannot be taken as alternative effective strategy towards reducing the negative impacts of climate change on South Africa sugarcane production. Management regimes and technologies were suggested in the study as better alternative and it is a more efficient method towards adapting to climate change in sugar cane production. 


\section{Methodology}

This paper is built on the theoretical foundation of the Cobb-Douglas production function as a means of establishing the factors that determine the quality of sucrose in the South African sugar cane milling industry. Bowle (1970) and Buchanan (1976) expanded the scope of the production function to incorporate linkages in the industry production possibilities of output and input, but with other possible factors are mainly controlled by technical relationships with the intention of gaining maximum profits. The Cobb-Douglas production function is built strongly on input and output relationship under which output in a given country $i$ at period $t$ takes the following form:

$Y_{t}=A L_{t}^{\beta} K_{t}^{\alpha}$

Based on the given equation (1) above, $Y_{t}=$ aggregate output in a period $t, A$ is the total factor productivity, $L_{t}$ is the labour input, $K_{t}$ is capital input, where $\beta$ and $\alpha$ are given as elasticity output of labour and capital, respectively. It is the level of technology that constantly influence these values.

In the where $\beta+\alpha=1$, then the Cobb-Douglas model indicates constant returns to scale. It simply indicates that when we double the input of and labour $L_{t}$ and capital $K_{t}$, it lead to double output, $Y_{t}$. On the other hand, if $\beta+\alpha>1$, it implies that increasing returns to scale set in and if $\beta+\alpha<1$, it indicates diminishing returns to scale.

Linearizing equation (1) leads to new equation (2) as follows:

$$
\log \left(Y_{t}\right)=\log (A)+\beta \log \left(L_{t}\right)+\alpha \log \left(K_{t}\right)
$$

A deviation takes place on Cob-Douglas production function as the study integrate agricultural product into production function as certain measures of output are determined by variables influencing them. The study attempts to adopt such variables used in literature, though not yet used in the South Africa, taking the forms in equations (1) and (2):

An equivalent of output $Y_{t}$ is giving by Sucrose $\left(\right.$ Sucr $\left._{t}\right)$ and $K_{t}$ and $L_{t}$ are to proxy all inputs in the production function. The functional relation is supported by Bowles (1970).

A Cobb-Douglas production function type is to be adopted, using the same variables such as: Sucrose, Avtm, Drn60, Ecref, Fao, Grow, Harvest, Rain, Sr100, Swc100 and TT16. This leads to the study's model specification.

Model Specification: Given that Avtm, Drn60, Ecref, Fao, Grow, Harvest, Rain, Sr100, Swc100 and TT16 would bear multiplicative relationship as inputs, we have:

Sucrose $=f($ Avtm, Drn60, Ecref , Fao, Grow, Harvest, Rain, Sr100, Swc100 ^ TT16)

At a time-series level, the linear relationship in the above equation yields:

$$
\begin{gathered}
\operatorname{lnSucrose}_{t}=\ln \alpha_{1} \text { Avtm }_{t}+\ln \alpha_{2} \text { Drn60 }_{t}+\ln \alpha_{3} \text { Ecref }_{t}+\ln \alpha_{4} \text { Fao }_{t}+\ln \alpha_{5} \text { Grow }_{t}+\ln \alpha_{6} \text { Harvest }_{t}+ \\
\ln \alpha_{7} \text { Rain }_{t}+\ln \alpha_{8} \operatorname{Sr}_{100_{t}}+\ln \alpha_{9} \text { Swc100 }_{t}+\ln \alpha_{10} \mathrm{TT}_{16} 6_{t}+\mu_{t}(4)
\end{gathered}
$$

Equation (4) leads to the ARDL model specification as follows:

The Model in ARDL format;

$$
\begin{aligned}
& \Delta \text { Sucrose }_{t}=c_{0}+\sum_{j=1}^{n} \beta_{1 j} \Delta \text { RSucrose }_{t-j}+\sum_{j=1}^{n} \beta_{2 j} \Delta \text { Avtm }_{t-j}+\sum_{j=1}^{n} \beta_{3 j} \Delta{\operatorname{Drn} 60_{t-j}}+\sum_{j=1}^{n} \beta_{4 j} \Delta \text { Ecref }_{t-j}+\sum_{j=1}^{n} \beta_{5 j} \Delta \text { Fao }_{t-j} \\
& +\sum_{j=1}^{n} \beta_{6 j} \Delta \operatorname{Grow}_{t-j}+\sigma_{1} \text { Harvest }_{t-1}+\sigma \operatorname{Rain}_{t-1}+\sigma_{3} \operatorname{Sr}_{100}+\sigma_{t-1} \operatorname{Swc} 100_{t-1}+\sigma_{5} \mathrm{TT}_{16} 6_{t-1}+U_{t} \ldots \ldots .
\end{aligned}
$$

Where: In Sucrose ${ }_{t}$ is the dependent variable, and Avtm, Drn60, Ecref, Fao, Grow, Harvest, Rain, Sr100, Swc100, and TT16 are the set of independent variables.

$\operatorname{Ln} A$ is the constant or intercept in the model, and $\mu_{\mathrm{t}}$ is the part is not captured by the growth of the following explanatory variables: Avtm, Drn60, Ecref, Fao, Grow, Harvest, Rain, Sr100, Swc100 and TT16.

$\alpha_{1}-\alpha_{10}$ are partial elasticity as given by each of the variables.

$\mu_{\mathrm{t},} \alpha_{\mathrm{t} 1}, \alpha_{\mathrm{t} 2,} \alpha_{\mathrm{t} 3,} \alpha_{\mathrm{t} 4, \ldots \ldots . .} \alpha_{\mathrm{t} 10}$ are the measurable constants, and according to this model, they are positively related to sucrose, hence they are to be positively signed according to a priori expectations. 
In line with equation (4) above, five steps are involved in carrying out a time series ARDL analysis: the ARDL time series unit root testing, the ARDL regression, ARDL Error Correction Model (ECM), diagnostic test, and analysis and interpretation of results.

Definition of variables: The variables used in the study are defined as follows:

- Average Temperature (AVTM): This is the sum of maximum temperature and minimum temperature divided by two to form the average temperature for the fourteen milling firms in South Africa.

- Deep Drainage at $60 \mathrm{~mm}$ (Drn60): This is the average soil water that percolates beyond the root zone (deep percolation) for a soil with a total available moisture of $60 \mathrm{~mm}$.

- Evaporation - reference sugar cane (Ecref): This averages the water loss through evaporation from the soil surface and transpiration from a fully canopied unstressed sugarcane crop.

- Evaporation - reference grass (Fao): This is a composition of all references on water loss through evaporation from the soil surface and transpiration from unstressed short green grass.

- Stalk growth - reference sugar cane (Grow): This is averages the total fresh cane growth of a full canopy unstressed sugarcane crop estimated as a function of incident solar radiation or crop water use, whichever is more limiting.

- Harvestable days - mechanically (Harvest): This is an average of mechanically harvestable days, determined from soil water content in the top $30 \mathrm{~mm}$ layer.

- (Rain): This is the average annual rainfall for all the mills within the cultivated period.

- Runoff $-100 \mathrm{~mm}$ (Sr100): This accounts for the average surface runoff (water flow) as a result of the soil being saturated with water for a soil with a total available moisture of $100 \mathrm{~mm}$.

- Soil Water Content - $100 \mathrm{~mm}$ (Swc100): This comprises of the averages of plant available soil water content calculated for rainfed conditions for a soil with a total available moisture (TAM) of $100 \mathrm{~mm}$ and with a full canopy cane crop growing on it.

- Thermal time $16^{\circ} \mathrm{C}$ (TT16): This is the average cumulative value of the mean daily temperature minus a threshold/base temperature of $16^{\circ} \mathrm{C}$, below which the rate of sugarcane development or growth is taken as zero.

Justification for adopting appropriate Model: Study have shown that unit root is common problem that must be addressed while running a time series analysis. To therefore determine the most appropriate method of regression analysis suitable for this analysis, the study consider the need to test for the stationarity of the variables using three different alternative measures. To achieve this, Giles (2013) submit three situations that pose a problems to data and offer the best alternative methods:

- Given a condition where every variable in the model are integrated of order I (0), Ordinary Least Square (OLS) model would be needed as the best methodology since all variable are stationarity.

- There are conditions under which every variable is non-stationary at $I(0)$, but when differenced could be become stationary at I(1), such situation requires the adoption of VECM as a preferred model (Johansen Cointegration Approach).

- Again, in situations where some variables have the mixture of both I(1) and I(0), Auto Regressive Distributive Lag (ARDL) is may be required (Chudik and Pesaran, 2013).

Data Sources: Data spanning the period between 1980 and 2016 on Average temperature (Avtm), Deep Drainage at $60 \mathrm{~mm}$ (Drn60), Evaporation with to reference sugar cane (Ecref), Evaporation with reference to grass (Fao), Stalk growth with reference to sugar cane (Grow), Harvestable days - mechanically (Harvest), Rain, Runoff - 100mm (Sr100), Soil Water Content (Swc100)and Thermal time $16^{\circ} \mathrm{C}(T T 16)$ are sourced from the South Africa Sugar Research institute (SASRI) website, while data on sucrose content in sugar was sourced from South Africa Sugar industry directorate 2016/2017 version.

\section{Results and Discussion}

Justification of Estimating Techniques: The estimating technique employed for this research work is the time series Autoregressive Distributed Lag (ARDL) approach of Chudik and Pesaran (2013), with the aim of testing for the existence of long and short run relationships between sucrose content in sugar cane and the 
variables that determine it. The study adopted ARDL methodology as the appropriate estimating technique due the following peculiar features with ARDL:

- When long run and short run dynamics are to be estimated, ARDL model offers the most recent valuable method (Giles, 2013).

- In conditions with a mixture of I(1) and I(0) data, ARDL model has been argued to be an appropriate techniques. Hence, it indicates that the method of estimation can be sequentially applied, most especially in cases of I(1), I(0), or mutually co-integrated and when their order of integration are mixed, however, ARDL cannot accommodate I(2) (Katircioglu, 2009).

- ARDL operates with automatic system selection of lags as they enter the model, and it can run appropriately with six variables (Giles, 2013).

- The long and short run regression of the model can be simultaneously estimated (Dritsakis, 2011).

- In the event of both small and large sample sizes, ARDL is mostly appropriate (Rafindadi and Yosuf, 2013).

In line with the above justification for our methodology, this study will employ the time series ARDL method according to Chudik and Pesaran (2013) to estimate the sucrose content in South African sugar cane. Faridi and Murtaza, (2014) among others have employed ARDL while using Cobb-Douglas production function.

Data Analysis and Interpretation: We report the results of the investigation carried out on the determinants of Avtm, Drn60, Ecref, Fao, Grow, Harvest, Rain, Sr100, Swc100 and TT16, which are the independent variables.

Table 2: Results from Augmented Dickey Fuller

\begin{tabular}{|c|c|c|c|}
\hline \multicolumn{4}{|c|}{ Augmented Dickey Fuller (Individual intercept) } \\
\hline Variables & $\mathrm{t}$ * Statistics & Order of Integration & P-Value \\
\hline AVTM & -4.817438 & $\mathrm{I}(0)$ & $0.0004^{* * *}$ \\
\hline DRN60 & -4.867868 & $\mathrm{I}(0)$ & $0.0003^{* * *}$ \\
\hline ECREF & -5.010527 & $\mathrm{I}(0)$ & $0.0002^{* * *}$ \\
\hline FAO & -5.076252 & $\mathrm{I}(0)$ & $0.0002^{* * *}$ \\
\hline GROW & -2.752692 & $\mathrm{I}(0)$ & $0.0753^{*}$ \\
\hline HARVEST & -5.203241 & $\mathrm{I}(0)$ & $0.0001^{* * *}$ \\
\hline RAIN & -4.820605 & $\mathrm{I}(0)$ & $0.0004^{* * *}$ \\
\hline SR0100 & -4.695419 & $\mathrm{I}(0)$ & $0.0006^{* * *}$ \\
\hline SUCROSE & -2.978819 & $\mathrm{I}(0)$ & $0.0465^{* *}$ \\
\hline SWC100 & -5.250974 & $\mathrm{I}(0)$ & $0.0001^{* * *}$ \\
\hline TT16 & -3.683665 & $\mathrm{I}(0)$ & $0.0087^{* * *}$ \\
\hline
\end{tabular}

Result for unit Root test in the model: To avoid spurious regression results in our study, this paper takes into account the need to test for unit root on the time series macro-variables in our model. Extant literature affirmed that most time-series macro-economic variables usually have stationarity problem and regressing non-stationary series could results in error that could threaten the validity/accuracy of our regression outcome. Hence, the study adopts a robust version of Augmented Dickey Fuller and Phillip-Perron and Dickey Fuller unit root test for this purpose. The study adopts the three methods to ascertain and validate the consistency of our results (Moon and Perron, 2004). The findings indicates that there is level stationarity for all the three methods, namely: Dickey Fuller, ADF-Fisher Chi Square, and Phillip Peron Unit root-test. The pvalues were tested at $10 \%, 5 \%$, and $1 \%$ respectively and as indicated in Tables 2,3 , and 4 . We accept the unit root result since there is consistency and the estimating technique adopted can incorporate I(0) and I(1) in the analysed regression. 
Table 3: Results from Dickey Fuller GLS

\begin{tabular}{llll}
\hline \multicolumn{2}{l}{ Dickey Fuller GLS (Individual intercept) } \\
Variables & $\mathbf{t}^{*}$ Statistics & Order of Integration & P-Value \\
\hline AVTM & -4.766138 & $\mathrm{I}(0)$ & $0.0000^{* * *}$ \\
DRN60 & -4.263975 & $\mathrm{I}(0)$ & $0.0001^{* * *}$ \\
ECREF & -4.453989 & $\mathrm{I}(0)$ & $0.0001^{* * *}$ \\
FAO & -4.409348 & $\mathrm{I}(0)$ & $0.0001^{* * *}$ \\
GROW & -2.678070 & $\mathrm{I}(0)$ & $0.0112^{* * *}$ \\
HARVEST & -4.019797 & $\mathrm{I}(0)$ & $0.0003^{* * *}$ \\
RAIN & -4.488013 & $\mathrm{I}(0)$ & $0.0001^{* * *}$ \\
SR0100 & -4.279773 & $\mathrm{I}(0)$ & $0.0001^{* * *}$ \\
SUCR0SE & -2.624016 & $\mathrm{I}(0)$ & $0.0128^{* *}$ \\
SWC100 & -4.006268 & $\mathrm{I}(0)$ & $0.0003^{* * *}$ \\
TT16 & -3.569667 & $\mathrm{I}(0)$ & $0.0011^{* * *}$ \\
\hline “***”, “**” and “*” represent statistical significance at $1 \%, 5 \%$, and $10 \%$ respectively
\end{tabular}

Table 4: Results from Phillip Peron

\begin{tabular}{llll}
\hline \multicolumn{2}{l}{ Phillip Peron (Individual intercept) } & \\
Variables & $\mathbf{t}^{*}$ Statistics & Order of Integration & P-Value \\
\hline AVTM & -4.801834 & $\mathrm{I}(0)$ & $0.0004^{* * *}$ \\
DRN60 & -4.937494 & $\mathrm{I}(0)$ & $0.0003^{* * *}$ \\
ECREF & -5.027942 & $\mathrm{I}(0)$ & $0.0002^{* * *}$ \\
FAO & -5.048722 & $\mathrm{I}(0)$ & $0.0002^{* * *}$ \\
GROW & -2.621172 & $\mathrm{I}(0)$ & 0.0981 \\
HARVEST & -5.187962 & $\mathrm{I}(0)$ & $0.0001^{* * *}$ \\
RAIN & -4.832512 & $\mathrm{I}(0)$ & $0.0004^{* * *}$ \\
SR0100 & -4.678649 & $\mathrm{I}(0)$ & $0.0006^{* * *}$ \\
SUCROSE & -2.866652 & $\mathrm{I}(0)$ & $0.0593^{*}$ \\
SWC100 & -5.245243 & $\mathrm{I}(0)$ & $0.0001^{* * *}$ \\
TT16 & -3.587831 & $\mathrm{I}(0)$ & $0.0110^{* *}$ \\
\hline “***”, “**” and “*” represent statistical significance at $1 \%, 5 \%$, and $10 \%$ respectively
\end{tabular}

Result and Discussion on the Time Series ARDL Regression Model: This section reports results from the time series ARDL regression analysis done on the South African sugar cane milling industry. The popularised ARDL estimating technique as proposed by Pesaran \& Pesaran (2010) was adopted with at least two lags. Table 5 presents the result of the time series ARDL estimated regression. According to the estimates from the time series regression, a high level of sucrose content is obtainable in both long and short runs, as most variables that determine sucrose content in sugar-cane are statistically significant at a $5 \%$ level of significance, except Soil Water Content - $100 \mathrm{~mm}$ (Swc100), which is not significant. It is evident that the variables under investigation tend to improve sucrose content in the South Africa Sugarcane industry if appropriate attention is given to their behaviour. 
Table 5: Results from Time Series ARDL

\begin{tabular}{|c|c|c|c|c|}
\hline \multicolumn{5}{|c|}{$\begin{array}{l}\text { Dependent Variable: SUCROSE } \\
\text { Method: Time Series ARDL } \\
\text { Sample: } 1980-2016 \\
\text { Model selection method: Akaike info criterion (AIC) } \\
\text { Selected Model: ARDL(2, 2, 2, 2, 2, 2, 2, 1, 2, 2, 2) }\end{array}$} \\
\hline \multicolumn{5}{|c|}{ Short-run Cointegrating Form } \\
\hline Variable & Coefficient & Std. Error & t-Statistic & Prob. \\
\hline D(SUCROSE $(-1))$ & 0.415227 & 0.037154 & 11.175707 & 0.0015 \\
\hline $\mathrm{D}(\mathrm{SR} 0100)$ & -0.008469 & 0.000482 & -17.568617 & 0.0004 \\
\hline D(SR0100(-1)) & 0.015909 & 0.000747 & 21.307105 & 0.0002 \\
\hline D(RAIN) & 0.007401 & 0.000327 & 22.631870 & 0.0002 \\
\hline D(RAIN $(-1))$ & -0.012874 & 0.000485 & -26.565897 & 0.0001 \\
\hline D(HARVEST) & 0.060107 & 0.002072 & 29.013529 & 0.0001 \\
\hline D(HARVEST(-1)) & -0.093860 & 0.003658 & -25.657408 & 0.0001 \\
\hline $\mathrm{D}(\mathrm{GROW})$ & 38.239732 & 1.283654 & 29.789752 & 0.0001 \\
\hline D(GROW(-1)) & 24.367272 & 0.955758 & 25.495238 & 0.0001 \\
\hline $\mathrm{D}(\mathrm{FAO})$ & -31.06625 & 1.148737 & -27.043840 & 0.0001 \\
\hline $\mathrm{D}(\mathrm{FAO}(-1))$ & 4.278805 & 0.508227 & 8.419079 & 0.0035 \\
\hline $\mathrm{D}$ (ECREF) & 8.063441 & 0.383741 & 21.012710 & 0.0002 \\
\hline D(ECREF $(-1))$ & -8.814526 & 0.334510 & -26.350540 & 0.0001 \\
\hline D(DRN60) & 0.001318 & 0.000368 & 3.578049 & 0.0373 \\
\hline D(AVTM) & -5.570829 & 0.207804 & -26.808064 & 0.0001 \\
\hline D(AVTM $(-1))$ & -1.577333 & 0.136116 & -11.588165 & 0.0014 \\
\hline D(SWC100) & -0.002789 & 0.002855 & -0.976830 & 0.4007 \\
\hline $\mathrm{D}(\mathrm{SWC100}(-1))$ & -0.061940 & 0.003197 & -19.374341 & 0.0003 \\
\hline D(TT16) & 0.024974 & 0.000851 & 29.334098 & 0.0001 \\
\hline D(TT16(-1)) & 0.010655 & 0.000511 & 20.865465 & 0.0002 \\
\hline
\end{tabular}

\section{Long Run Coefficients}

\begin{tabular}{lllll} 
Variable & Coefficient & Std. Error & t-Statistic & Prob. \\
SR0100 & -0.004502 & 0.001384 & -3.253732 & 0.0474 \\
RAIN & 0.005088 & 0.000588 & 8.648131 & 0.0033 \\
HARVEST & 0.051463 & 0.005617 & 9.162409 & 0.0027 \\
GROW & 11.570062 & 1.308137 & 8.844686 & 0.0030 \\
FAO & -17.54530 & 2.100031 & -8.354785 & 0.0036 \\
ECREF & 6.843537 & 1.087776 & 6.291309 & 0.0081 \\
DRN60 & 0.005439 & 0.001577 & 3.448763 & 0.0410 \\
AVTM & -3.894437 & 0.348141 & -11.186389 & 0.0015 \\
SWC100 & 0.017636 & 0.010036 & 1.757219 & 0.1771 \\
TT16 & 0.016084 & 0.001021 & 15.757655 & 0.0006 \\
C & 68.369306 & 6.301726 & 10.849299 & 0.0017 \\
\hline
\end{tabular}

Data Analysis and Interpretation: A total of ten variables (among the variables that show a tendency to influence sucrose quality) entered the ARDL regression model, as indicated in the table 5. The results show that the variables have a high tendency to improve sucrose content in sugar cane both in the long and short run. This is because all variables exhibit significant relationships except Content of Soil Water (Swc100). The coefficient signs of these variables are important, as they give further details about the impact of these variables on the dependent variable. For instance, a 1\% increase in the Runoff ( $\mathrm{Sr} 100)$ will cause sugar cane sucrose content to decrease by $0.8 \%$ in the short-run and by $0.5 \%$ in the long-run. However, the reverse is the case in the previous season, where a $1 \%$ increase in the Runoff $-100 \mathrm{~mm}$ causes a $1.5 \%$ increase in sucrose content. Similarly, both short and long run, a $1 \%$ increase in rainfall will increase sucrose by $0.7 \%$ in the short run and $5.1 \%$ in the long-run. Similarly, mechanically harvestable day has the possibility of improving sucrose content. There could be $6.0 \%$ and $5.1 \%$ increments in sucrose content in the short and long runs respectively as result of a 1-day increase in the harvestable day. In summary, the study found consistency in 
the result obtained both in the short and long run. For instance, Growth of stock, Evaporation, Deep drainage and Thermal time at the temperature of $16^{\circ}$ cvalues would increase sucrose quality with a $1 \%$ increase in the variables' coefficients. This is also true in the long run. However, the study revealed a reverse relationship among evaporation with reference to grass, lag in evaporation, Average temperature, and its lag. An increase in these variables would decrease sucrose content in sugar cane by the coefficient value level.

Inferences, Comparison with Previous Empirical Studies and Discussion of Findings: The results indicate a negative relationship between sucrose content and Evaporation - Reference grass (Fao), Evaporation - Reference Sugar cane (Ecref) and the lag of Ecref, and Average Temperature (AVTM) and its lag, which is contrary to a priori expectation and existing theory. They support the findings of Buchanan (1976) who found in his simple time regression analysis an inverse relationship between sucrose, harvestable components and water related contents. Deressa, Hassan \& Poonyth (2005) also noted that precipitation and temperature negatively and significantly affect sugarcane production in South Africa. The adoption of regression analysis to determine the impacts of these explanatory variables on sucrose has not been exploited much in literature. However, results have shown how sucrose could be increased in the production of sugar cane given the consideration of the available variables under investigation. The component proportions that will lead to increment have been identified. The study contributes to the body of knowledge in the following ways: (1) we employed a more sophisticated estimating technique in the determination of factors that could enhance sucrose increase in sugar cane which before now has not been used. (2) we provide evidence to support the increase of sucrose by moderating the increase of Growth of stock, Evaporation, Deep drainage, Thermal time and the temperature in the plantation periods and hence the increase in more sugar. The policy implication of our study to South Africa sugar industry is that more attention should be given to various planting season and possible weather variations as this variation could inhibit the quality of sugar cane product for the planting season and hence decrease expected revenue for both the farmer, the industry and South African government.

Table 6: Serial Correlation

\begin{tabular}{lcll}
\hline \multicolumn{4}{l}{ Breusch-Godfrey Serial Correlation LM Test: } \\
\hline F-statistic & 1.243341 & Prob. F(2,1) & 0.5355 \\
Obs*R-squared & 24.96180 & Prob. Chi-Square(2) & 0.0000 \\
\hline
\end{tabular}

Source: Authors' Computation

$H_{0}$ :There is no serial correlation among the paired independent variables and the dependent variable.

$H_{1}$ :There is serial correlation among the paired independent variables and the dependent variable.

Decision rule: Accept null hypothesis $\left(\mathrm{H}_{0}\right)$ when $\mathrm{p}$-Value is greater than $5 \%$.

Reject null hypothesis $\left(\mathrm{H}_{0}\right)$ when $\mathrm{p}$-Value is less than $5 \%$.

The results from serial correlation are shown in Table 6 . The probability value in the table indicates that the F-statistics p-Value is greater than $5 \%$. We therefore reject the null hypothesis and accept the alternative hypothesis, implying that there is no serial correlation in the model.

Time series-ARDL Regression Analysis Model and its strength Measurement: The study requires determination of the short and long run nexus as well as the strength of the Akaike Information Criterion (AIC) model selection summary on other models (the Hannan-Quinn criterion and Schwarz criterion) in the regression model. A Criteria graph has been employed to determine the top twenty (20) different seriesARDL models. The bench mark for the model analysed shows "that lower value of the AIC, behaves better in the model". From Figure 1, the first ARDL $(2,2,2,2,2,2,2,1,2,2,2)$ model seems to be mostly preferred over others, since it provides the lowest possible value (-.2.8) in the Akaike Information Criterion. The ARDL $(2,2$, $2,2,2,2,2,1,2,2,2)$ model appears to be the next with a -2.8 value as shown in the criteria graph. 


\section{Figure 1: Akaike Information Criterion (Top 20 models)}

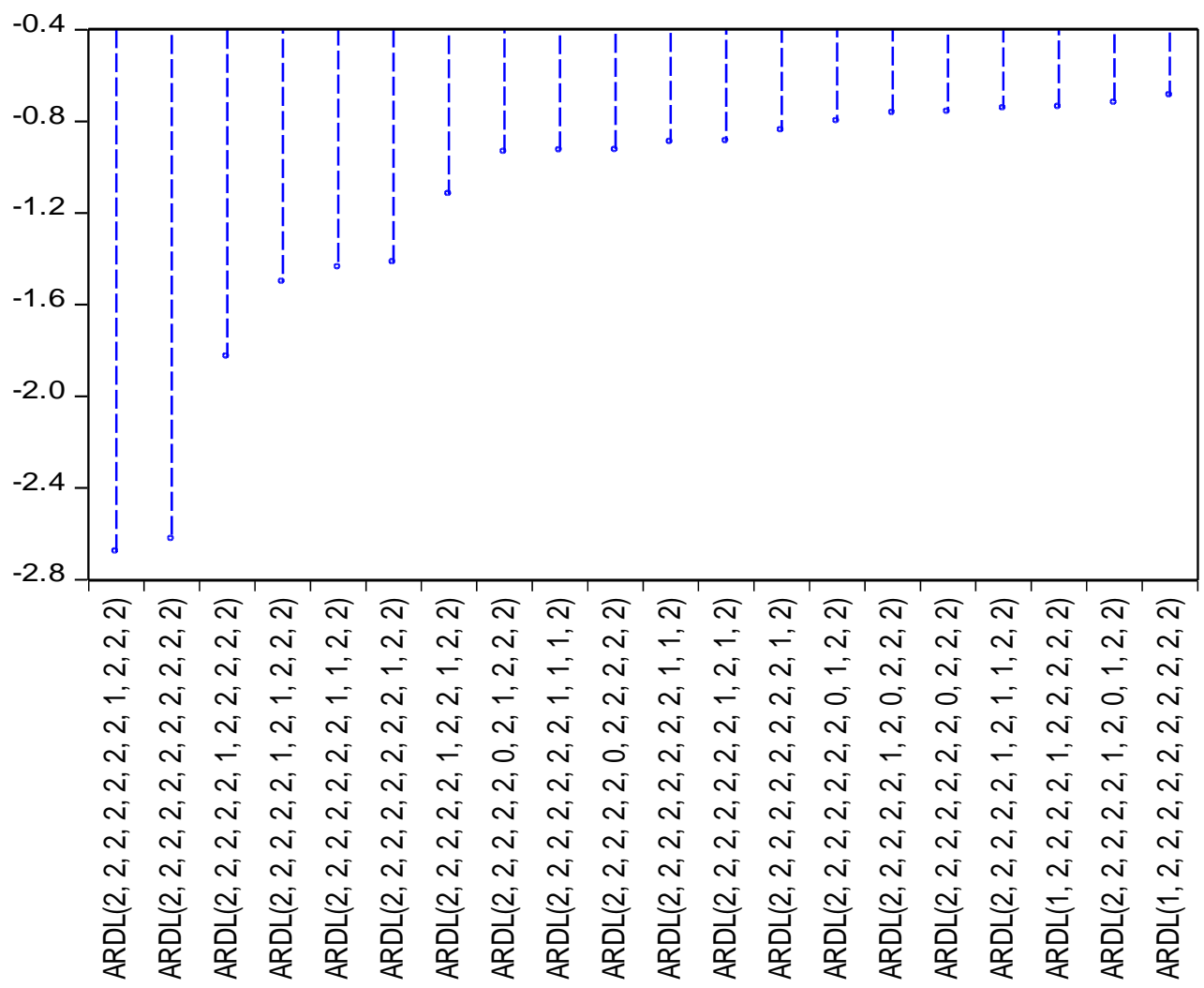

Table 8: ECM Analysis

\begin{tabular}{lllll}
\hline Variable & Coefficient & Std. Error & t-Statistic & Prob. \\
\hline CointEq(-1) & -2.258148 & 0.074588 & -30.274923 & 0.0001 \\
\hline
\end{tabular}

Time Series-ARDL Error Correction Model: In Table 8, we use Error Correction Model (ECM) analysis to investigate the short run and long run dynamics of our model. The ECM coefficient reveals the speed of adjustment - how slowly or quickly the variables are expected to return to equilibrium. The negatively-signed coefficient of the ECM established an existing disequilibrium in the past, but the system is getting adjusted in the right direction. An ECM value of -2.258 suggests that there is a speed of adjustment from the short run deviation to the long run equilibrium of those factors that determine sucrose variables. Furthermore, we noted that long run equilibrium can be attained since the ECM is statistically significant at $5 \%$. Our findings conform to the result of Banerjee, Dolado \& Mestre (1998) and Rabbi (2011) who argued that a strong significant ECM value establishes proof of the existence of a stable long run association. Our findings further show that there will be convergence (steady-state) of the system and the attainment of high rate of sucrose in sugar is expected in the long run.

Table 9: Bound Testing

Null Hypothesis: No long-run Relationships exist

\begin{tabular}{lll}
\hline Test Statistic & Value & K \\
\hline F- Statistic & 16.36734 & 10 \\
Critical Value Bounds & & \\
Significance & I0 Bound & I1Bound \\
$10 \%$ & 1.76 & 2.77 \\
$5 \%$ & 1.98 & 3.04 \\
$2.5 \%$ & 2.18 & 3.28 \\
$1 \%$ & 2.41 & 3.61 \\
\hline
\end{tabular}


Test for Heteroskedasticity: We again ran the bound test to further establish the long run relationship among these variables. It is traditional that the value of $F$-statistics must be higher than both the lower and higher value of the upper bound. As indicated in the table, the value of 16.36734 is higher than 3.61 and 2.41. This further establishes the fact that there exists a long run relationship among the variables in question.

Table 10: Heteroskedasticity Test: Breusch-Pagan-Godfrey

\begin{tabular}{llll}
\hline F-statistic & 1.264954 & Prob. F(31,3) & 0.4916 \\
Obs*R-squared & 32.51265 & Prob. Chi-Square(31) & 0.3922 \\
Scaled explained SS & 0.447050 & Prob. Chi-Square(31) & 1.0000 \\
\hline
\end{tabular}

Test for heteroskedasticity was carried out on the regression analysis where it is expected that the variance of the error term be constant for all levels of observation. If this assumption is violated, then a heteroskedasticity problem sets in. We used the Breusch-Pagan-Godfrey test to confirm the existence of heteroskedasticity. The rule of thumb here is that three probability values must not be significant. As indicated in our table, this condition was met in our results, meaning that no heteroskedasticity exists in the model.

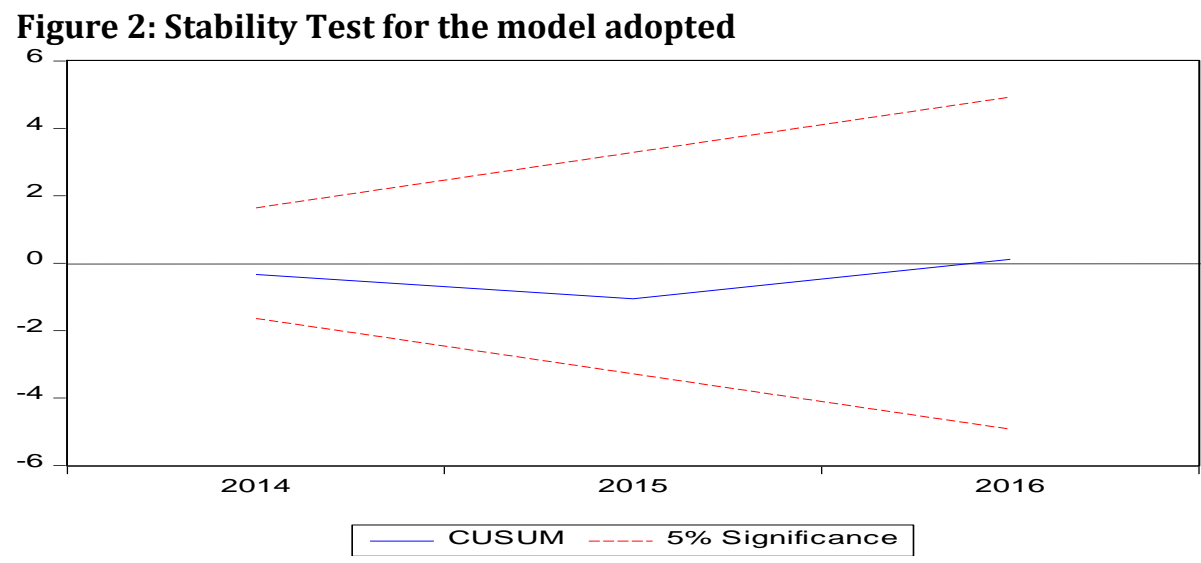

Furthermore, stability test has been carried out in this research work on recursive residual using Cusum procedure at $5 \%$ level of significance. It is evident that if the blue line falls within the two red lines, it shows that the regression is stable and it further confirms that there is long run relationship as shown in the figure above.

\section{Figure 3: Normality tests}

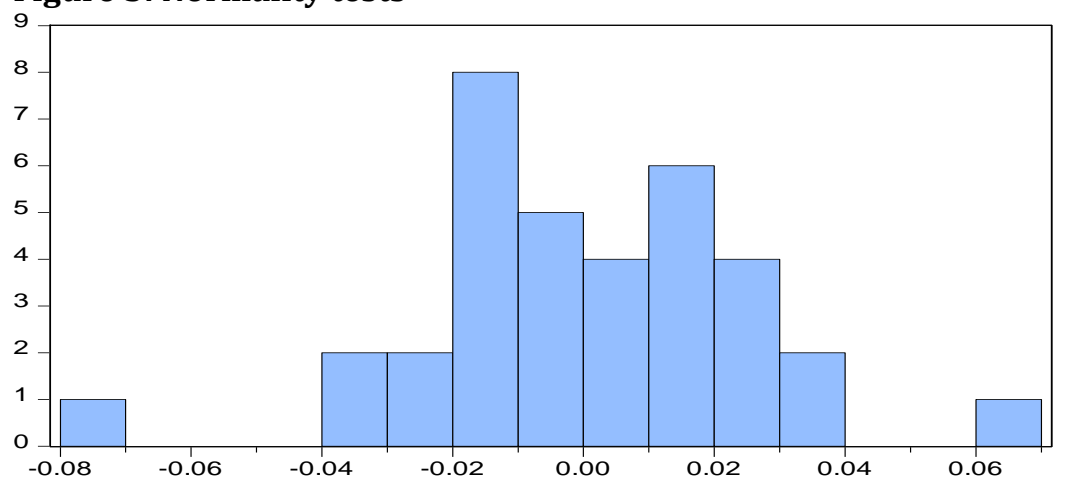

\begin{tabular}{lr} 
Series: Residuals \\
Sample 1982 2016 \\
Observations 35 \\
Mean & $-5.69 \mathrm{e}-15$ \\
Median & -0.001683 \\
Maximum & 0.066620 \\
Minimum & -0.079797 \\
Std. Dev. & 0.025771 \\
Skewness & -0.314965 \\
Kurtosis & 4.743062 \\
& \\
Jarque-Bera & 5.009486 \\
Probability & 0.081697 \\
\hline
\end{tabular}

Again, Normality Test was carried out to ascertain if the data adopted is normally distributed on our regression analysis. From a priori expectation, except the Kurtosis to be skewnedaround 3.0for a normal distribution, we. If $\boldsymbol{K}>\mathbf{3} \rightarrow$ excess height, above average height. Our Kurtosis value of 4.7 fits in by approximation and revealed that our model is normally distributed. Jarque-Bera: J-Bera is a perfect test for normality. It is a combination of both Skewness and Kutosis. The normal standard or Decision Rule:If $\boldsymbol{J}$-B $<$ 
$5.99 \rightarrow$ We do not reject the $H_{o}$ (i.e. there is normality). If $\boldsymbol{J}-\boldsymbol{B}>\mathbf{5 . 9 9} \rightarrow$ We reject the $H_{\mathrm{o}}$ (i.e. there is no normality). Again, with Jarque Bera Value of 5.009 , we do not reject $\mathrm{H}_{\mathrm{o} . \text {, }}$ meaning there is normality.

Table 11: Short-Run Causality Tests

\begin{tabular}{|c|c|c|c|}
\hline \multirow[b]{2}{*}{ Statistics } & \multicolumn{3}{|c|}{ EQUATION: P-ARDL, $\mathrm{HO}=\mathrm{C}(1)=\mathrm{C}(2)=0$} \\
\hline & VALUE & DF & PROBABILITY \\
\hline \multirow[t]{2}{*}{ F -statistics } & 17.96141 & $(2,3)$ & 0.0214 \\
\hline & \multicolumn{3}{|c|}{ EQUATION: P-ARDL, $\mathrm{H} 0=\mathrm{C}(2)=\mathrm{C}(3)=0$} \\
\hline Statistics & VALUE & $\mathrm{DF}$ & PROBABILITY \\
\hline \multirow[t]{2}{*}{ F -statistics } & 10.73110 & $(2,3)$ & 0.0429 \\
\hline & \multicolumn{3}{|c|}{ EQUATION: P-ARDL, $\mathrm{H} 0=\mathrm{C}(3)=\mathrm{C}(4)=0$} \\
\hline Statistics & VALUE & $\mathrm{DF}$ & PROBABILITY \\
\hline \multirow[t]{2}{*}{ F -statistics } & 1.512483 & $(2,3)$ & 0.3514 \\
\hline & \multicolumn{3}{|c|}{ EQUATION: P-ARDL, $\mathrm{H} 0=\mathrm{C}(4)=\mathrm{C}(5)=0$} \\
\hline Statistics & VALUE & $\mathrm{DF}$ & PROBABILITY \\
\hline \multirow[t]{2}{*}{ F -statistics } & 21.99715 & $(2,3)$ & 0.0161 \\
\hline & \multicolumn{3}{|c|}{ EQUATION: P-ARDL, $\mathrm{H} 0=\mathrm{C}(5)=\mathrm{C}(6)=0$} \\
\hline Statistics & VALUE & $\mathrm{DF}$ & PROBABILITY \\
\hline \multirow[t]{2}{*}{ F -statistics } & 37.66610 & $(2,3)$ & 0.0075 \\
\hline & \multicolumn{3}{|c|}{ EQUATION: P-ARDL, $\mathrm{H} 0=\mathrm{C}(6)=\mathrm{C}(7)=0$} \\
\hline Statistics & VALUE & $\mathrm{DF}$ & PROBABILITY \\
\hline \multirow[t]{2}{*}{ F -statistics } & 59.50756 & $(2,3)$ & 0.0039 \\
\hline & \multicolumn{3}{|c|}{ EQUATION: P-ARDL, $\mathrm{H} 0=\mathrm{C}(7)=\mathrm{C}(8)=0$} \\
\hline Statistics & VALUE & $\mathrm{DF}$ & PROBABILITY \\
\hline \multirow[t]{2}{*}{ F -statistics } & 53.33957 & $(2,3)$ & 0.0045 \\
\hline & \multicolumn{3}{|c|}{ EQUATION: P-ARDL, $\mathrm{H} 0=\mathrm{C}(8)=\mathrm{C}(9)=0$} \\
\hline Statistics & VALUE & $\mathrm{DF}$ & PROBABILITY \\
\hline F-statistics & 13.30528 & $(2,3)$ & 0.0322 \\
\hline
\end{tabular}

Source: Author's calculation

Short-Run Causality Tests among the Determinants of Sucrose Quality: The study further considered the possibility of two variables jointly impacting on the short-run. Increase in sucrose quality. In the wald test model: $\mathrm{C} 1=$ Avtm; $\mathrm{C} 2=$ Drn60; $\mathrm{C} 3=\mathrm{Ecref} ; \mathrm{C} 4=\mathrm{Fao}$;

$\mathrm{C} 5=$ Grow; $\mathrm{C} 6=$ Harvest; $\mathrm{C} 7=$ Rain; $\mathrm{C} 8=\mathrm{Sro} 100 ; \mathrm{C} 9=\mathrm{Tt} 16$; $\mathrm{C} 10=\mathrm{Swc} 100$. The results indicate that all the pairs of variables could jointly impact on sucrose level in the short run, except for the pair of C(4) and C(5), namely Evaporation - Reference grass and Stalk growth - Reference sugar cane, whose p-Values are not significant. This implies that both variables cannot jointly cause sucrose to increase at the short-run.

\section{References}

Anon (2014). Tongaat Hulett Limited - Integrated Annual Report. Durban

Anon. (2016). Tongaat Hulett Limited - Integrated Annual Report. Durban.

Banerjee, A., Dolado, J. \& Mestre, R. (1998). Error-correction mechanism tests for cointegration in a single-equation framework. Journal of time series analysis, 19(3), 267-283.

Bowles, S. (1970). Towards an educational production function Education, income, and human capital (pp. 11-70): NBER.

Buchanan E. J. (1976). The effect of cane quality on factory performance how important is it?Proceedings of The South African Sugar Technologists' Association.

Chudik, A. \& Pesaran, M. (2013). Large Panel Data Models with Cross-Sectional Dependence: a Survey. CAFE Research Paper, 13(15).

Deressa, T., Hassan, R. \& Poonyth, D. (2005). Measuring the impact of climate change on South African agriculture: the case of sugarcane growing regions. Agrekon, 44(4), 524-542.

Dritsakis, N. (2011). Demand for Money in Hungary: An ARDL Approach. Review of Economics and Finance, 5, 1-28.

Eggleston, G. (2010). Sustainability of the sugar and sugar-ethanol industries. American Chemical Society, Washington DC, USA. 
Faridi, M. Z. \& Murtaza, G. (2014). Disaggregate Energy Consumption, Agricultural Output and Economic growth in Pakistan: An ARDL Modelling Approach to Co-integration. www.pide.org.pk/psde/pdf/AGM29/papers/Muhammad Zahir Faridi.pdf

Giles, D. (2013). ARDL Models-Part II-Bounds Tests. Econometrics Beat, 19.

Jorge, L. M. M., Righetto, A. R., Polli, P. A., Santos, O. A. A. \& MacielFilho, R. (2010). Simulation and analysis of a sugarcane juice evaporation system. Journal of Food Engineering, 99, 351-359.

Katircioglu, S. T. (2009). Revisiting the tourism-led-growth hypothesis for Turkey using the bounds test and Johansen approach for cointegration. Tourism Management, 30(1), 17-20.

Kwenda, P. R. (2015). A Review of the Sugar Milling Process in South Africa and how it influences the Length of Milling Season. MSc Bio-resources Systems. University of KwaZulu-Natal, School of Engineering.

Martinelli, L. A. \& Filoso, S. (2008). Expansion of sugarcane ethanol production in Brazil: environmental and social challenges. Ecological Applications, 18, 885-898.

Meyer, J., Rein, P., Turner, P. \& Mathias, K. (2013). Good management practices for the cane sugar industry. Germany.

Meyer, J. \& Wood, K. (2001). The Effects of Soil Fertility and Nutrition on Sugarcane Quality: A Review. South African Sugar Association Experiment Station, South Africa.

Moon, H. R. \& Perron, B. (2004). Testing for a unit root in panels with dynamic factors. Journal of econometrics, 122(1), 81-126.

Moor, G. M. \& Wynne, A. T. (2001). Economic maximisation of grower and miller sugar cane profits: Optimising the length of milling season at South African sugar factories. Proceedings of the International Society of Sugar Cane Technologists, 24, 245-249.

Orgeron, A. J. (2012). Sugarcane growth, sucrose content, and yield response to the ripeners glyphosate and trinexapacethyl. PhD Dissertation, School of Plant, Environmental, and Soil Sciences, Louisiana State University digitalcommons.lsu.edu/cgi/viewcontent.cgi?article $=2361 \&$ context $=$

Pesaran, B. \& Pesaran, M. H. (2010). Time series econometrics using Microfit 5.0: A user's manual: Oxford University Press, Inc.

Rafindadi, A. A. \& Yosuf, Z. (2013). An application of panel ardl in analysing the dynamics of financial development and economic growth in 38 sub-saharan african continents. Paper presented at the Proceeding-Kuala Lumpur International Business, Economics and Law Conference.

Rabbi, F. (2011). Effectiveness of Monetary Policy in Pakistan: Empirical Evidences based on Bound Test Approach.

Rein, P. (2007). Cane sugar engineering, VerlagDr. Albert Bartens, Berlin, Germany.

Roberts, S. (2017). The fundamentals of sucrose accumulation in sugarcane. Retrieved from http://www.fertilizer.co.za/public-relations/news/2017/239-the-fundamentals-of-sucroseaccumulation-in-sugarcane.

Sparovek, G. \& Schnug, E. (2001). Temporal Erosion-Induced Soil Degradation and Yield Loss. Soil SciSoc Am J., $65,1479-1486$.

Tominaga, T. T., Cássaro, F. A. M., Bacchi, O. O. S., Reichardt, K., Oliveira, J. C. M. \& Timm, L. C. ( 2002). Variability of soil water content and bulk density in a sugarcane eld. Australian Journal of Soil Research, 40, 605-614.

Tongaat, H. (2012). Bioenergy Potential of Sugarcane. Provincial Planning Commission, Province of KwazuluNatal.

Wang, C., Peng, J., Li, H., Bi, X. T., Legros, R., Lim, C. J. \& Sokhansanj, S. (2013). Oxidative torrefaction of biomass residues and densification of torrefied sawdust to pellets. Bioresource Technology, 127(1), 318-325.

Watanabe, K., Nakabaru, M., Taira, E., Ueno, M. \& Kawamitsu, Y. (2016). Relationship between nutrients and sucrose concentrations in sugarcane juice and use of juice analysis for nutrient diagnosis in Japan, Agronomy and crop Ecology. http://dx.doi.org/10.1080/1343943X.2015.1128106

Whittaker, A. \& Botha C.F. (1997). Carbon Partitioning during Sucrose Accumulation in Sugarcane lnternodal Tissue, Department of Biotechnology, South African Sugar Association Experiment Station, Mount Edgecombe, KwaZuluNatal 4300, South Africa. Plant Physiol, 115, 1651-1 659. https://www.researchgate.net/profile/Frikkie_Botha/publication/...

Wood, R. A. (1982). Nutrition and cane quality. S AfrSugAgron Ass.

Wynne, A. T. \& Groom, G. (2003). Technical parameters used to measure and monitor length of milling season in the South African sugar industry. Proceedings of the South African Sugar Technologists' Association, Durban, South Africa, 77, 63- 76. 